\title{
Just War Reasoning in an Age of Risk
}

Esther D. Reed

\begin{abstract}
The classic, theological tradition of just war reasoning (JWT) is not exhausted but needed more-than-ever in the shadow of global risks, when facing 'hybrid' war, and when the difference between war and peace is said to be blurring. The tradition does not speak with one voice but debate within the tradition about the (un)acceptability of military action under conditions of uncertainty sheds light, in at least three ways, on ways of approaching the range of unorthodox tactics threated in conflict today:

1. How to be fearful. Fear and anxiety in an age of risk are potential threats to reason. The JWT has resources with which to consider 'how to fear' wisely.

2. How to grapple with issues of classification, including what constitutes an attack equivalent to an 'armed attack' under UN Charter Art 51. When, for instance, are cyber attacks are better dealt with under civilian, international commercial law, and when the laws of war?

3. How to approach new challenges in a principled manner. Are different principles or criteria are needed to govern action (e.g., the criterion of intensity) or do immediacy and necessity remain the most critically important principles in our moral arsenal?
\end{abstract}

\section{The Concept of Risk Today}

Since Mary Douglas and Aaron Wildavsky worked on risk, culture and perceptions of uncertainty in the 1980s, a central assumption in sociology and political theory has been that risk is a social construction in particular historical and cultural contexts. ${ }^{1} \mathrm{We}$ are interested in this essay in how risk management and the securitization mindset are affecting attitudes to armed conflict and its regulation by international law, and consider cyber attacks as a mode of securitization that is becoming militarized. (Related questions about whether violence is becoming therapeutically calming to the social psyche, and whether there is evidence of politicians invoking risk rhetorically for questionable advantage, are relevant but outside our immediate scope.) The claim is that the classic, theological tradition of just war reasoning (JWT) is not exhausted but needed more-than-ever in the shadow of global risks, when facing 'hybrid' war, and when the difference between war and peace is said to be blurring.

Ulrich Beck brought the concepts of risk and risk research to prominence in sociology and social theory over the past few decades, and is widely recognised has having expressed concerns about the consequences of modernity, fears about risk and security as a result of

\footnotetext{
${ }^{1}$ Mary Douglas and Aaron Wildavsky. Risk and Culture: An essay on the selection of technical and environmental dangers (University of California Press, 1982).
} 
globalisation and its implications for the state and social organisation. ${ }^{2}$ I broadly suppose Beck's idea of 'the risk society' as shorthand for his account of the transition from 'modern' industrial societies wherein, broadly speaking, risk was conceived as calculable to 'postmodern' societies trust in the calculability of risk is waning, new paradigms of uncertainty become entrenched, and a sense of global risk opens up complex moral and political spaces of responsibility individuals must negotiate for themselves. Risk as we are experiencing it, for Beck, is a phenomenon of a godless world wherein anxiety is becoming the dominant cultural grammar, with risks experienced at the national level inseparable from risks at the global level that are variously economic, environmental, geopolitical, societal and technological. ${ }^{3}$ of interest for our purposes is how risk management and the securitization mindset is affecting attitudes to armed conflict and its regulation by international law.

The so-called 'risk society' thesis and accompanying risk assessments have found their way into international relations, military strategy documents and, indeed, the UK National Security Strategy 2010 (NSS) which is intended to guide the on-going Strategic Defence and Security Review in its delivery of national security, albeit with further reports, until $2015 .{ }^{4}$ The NSS sets out a 'whole government' approach to security, and headlines high priority risks: international terrorism, cyber attack, international military crises (including those prompted by nuclear weapons proliferation) and large-scale civil emergencies, major accidents or natural hazards. It is a relatively brief document but its significance, says Michael Clarke, Director, RUSI, is that it turns the traditional conception of security on its head. 'What is to be defended, it says, is not so much the territory of Britain or even the organs of the British state, so much as the way of life of the people of Britain; their ability to go about their business here and in the rest of the world freely and with confidence'. ${ }^{5}$ It's not really a strategy as such, says Clarke, in that it 'does not make hard choices between real things - which is what strategists have to do' but points to threats that should be taken seriously, and reminds is readers that the risk picture is likely to become increasingly diverse. 'No single risk will dominate' but the highest priority risks are those arising from international terrorism, cyber attack (including by other states, and

\footnotetext{
${ }^{2}$ Ulrich Beck, World Risk Society (Polity Press, 1999). On this, see S.L. Darryl and D.S. Jarvis, 'Risk, Globalisation and the State: A Critical Appraisal of Ulrich Beck and the World Risk Society Thesis', Global Society, Vol. 21, No. 1, January, 2007, p.23.

${ }^{3}$ Beck, World Risk Society, p.333.

${ }^{4}$ UK National Security Strategy 2010 (NSS)

https:/www.gov.uk/government/uploads/system/uploads/attachment data/file/61936/national-securitystrategy.pdf (accessed: 19 October, 2014).

${ }_{5}^{5}$ Preliminary RUSI Briefing: The National Security Strategy 2010, 18 Oct 2010. https:/www.rusi.org/analysis/commentary/ref:C4CBC6D8637AB7/\#.VARL6EsWA8M (accessed: 19 October, 2014).
} 
by organised crime and terrorists), international military crises, large scale civil emergencies, and major accidents or natural hazards. ${ }^{6}$

Christopher Coker has commented most directly on how national security strategies have moved in recent years from preoccupation with deterrence, defence and imminent dangers, to the language and practices of risk, awareness, pre-emption, precaution, surveillance, and vulnerability. ${ }^{7}$ His observations on the effects of anxiety before an unknown and uncertain future stand out. As governments lack confidence that we can manage risk and strategize insecurity, Coker underscores the role of anxiety as the dominant logic of the risk society. 'What is specific to many of our own anxieties', he argues 'is that they exist in the absence of any looming historical disaster'. ${ }^{8}$ Donald Rumsfeld's phrase 'unknown unknowns' is symptomatic of an important change rather than simply a tautological coinage and expresses high levels of anxiety in the face of uncertainty, unknown risks and the almost ungraspable complexity of the risks that we can begin to anticipate. Against this backdrop, Coker considers some of the consequences of the new logic of strategy and politics as formed by 'the unknown, the uncertain, the unseen and the unexpected' and asks whether war and violence are becoming self-sustaining in the face of 'unknown unknowns'. ${ }^{9}$ Coker anticipates an increasing petrification of political processes and overly quick justification of violent responses to an increasingly wide range of risks: 'We are now in the business of 'managing insecurity' or 'enabling greater or lesser stability' or guaranteeing better 'service provision'. ${ }^{10}$

For present purposes, I adopt Coker's broad sub-division of discourse about risk into:

$>$ risk as threat

$>$ risk as managing insecurity

$>$ risk as entailing the need to maintain 'service provision'.

Of interest is whether the JWT is capable of responding to this new context or is losing relevance to the most critical strategic choices in a context where 'risk registers' are now part of our NSS and as the language of risk assessment is commonplace in international relations. More specifically, we are interested in the characteristics of the anxiety that anticipates an unknown and uncertain future and whether the JWT's precepts are losing direct relevance to

\footnotetext{
${ }^{6}$ NSS, 1.32 .

${ }^{7}$ Christopher Coker, War in an Age of Risk (Polity Press, 2009). For an excellent review, see Claudia Aradau in Ethics and International Affairs, Volume 24.1 (Spring 2010).

${ }^{8}$ Coker, War in an Age of Risk, p.73.

${ }^{9}$ Coker, War in an Age of Risk, p. ix.

${ }^{10}$ Coker, War in an Age of Risk, p.17. Aradnau's summary is useful: 'While enmeshed in speculations about the future, the risk society appears to paradoxically lack a future that would radically change the status quo'.
} 
the most critical strategic choices. 'Its abstracted set of conventions' says Paul Schulte, a former senior official in the UK Ministry of Defence and Department of International Development, no longer grips the increasingly convoluted landscapes of twenty-first-century conflict' and have lost moral traction. Statesmen, philosophers, soldiers, and lawyers will have to work hard to rethink JWT's intellectual purchase on events. ${ }^{11}$

I have explicated elsewhere some of the reasons why the JWT criteria are said to be stretched to breaking point in other contexts. ${ }^{12} \mathrm{We}$ are interested here in whether the narrowly judicial JWT misses the target, so to speak, with its criteria of 'right authority', 'just cause', 'rightful intention', when the mindset at policy level is about identifying and minimizing risk, minimizing risk exposure, doing the cost / benefit analysis with respect to national interest, reassuring and training the public about security. Are the JWT and 'risk society' talking past one another? Or, as I suggest, does the JWT put urgently important questions to the "risk society' about inter alia the ethical implications of placing risk at the centre of natural security policy, and how to theorise the relation between 'just war' and risk?

\section{Risk and the Just War Tradition}

Before proceeding to explicate why and how the JWT puts questions to the 'risk society', it is necessary to underline that just war reasoning is not all the same. Distinction may be drawn between the narrowly penal, judicial JWT (with theological roots in the writings inter alia of Ambrose, Augustine, Aquinas, Gratian, Isidore of Seville, the canon lawyers of the eleventh and twelfth centuries and the Salamancan school of moral theology) and what Richard Tuck dubs the modern humanist tradition (Gentili, Grotius, Hobbes, Pufendorf through to Walzer and Rawls). ${ }^{13}$ At the heart of differences between the narrow, theological tradition and the looser secularist, humanist tradition is the progressive reduction of natural law reasoning to a narrow set of rights and the single, normative principle of national self-defence. We are interested predominantly in the resources of the classic theological, narrowly judicial JWT with a view to arguing that its resources shed light on ways of approaching the range of unorthodox tactics threated in conflict today:

1. How to be fearful when, in an age of risk, fear and anxiety are potential threats to reason. The claim is that the JWT has resources with which to consider 'how to fear' wisely.

\footnotetext{
${ }^{11}$ Paul Schulte, 'Morality and War' in Oxford Handbook of War (OUP, 2012), p.113.

12 Esther D. Reed, Theology for International Law (T and T Clark, 2013), ch. 5.

${ }^{13}$ Richard Tuck, The Rights of War: Political Thought and the International Order from Grotius to Kant (OUP, 2001).
} 
2. How to grapple with issues of classification, including what constitutes an attack equivalent to an armed attack under UN Charter Art 51. When, for instance, are cyber attacks better dealt with under civilian, international commercial law, and when the laws of war?

3. How to approach new challenges of the 'risk society' in a principled manner. Are different principles or criteria are needed to govern action (e.g., the criterion of intensity) or do immediacy and necessity remain the most critically important principles in our moral arsenal?

Even within the JWT we find differing emphases regarding attitudes to self-defence in the face of threat. Any suggestion, however, that the JWT and 'risk society' must talk past one another because the former is backward looking to wrongs committed and the latter forward looking to threats ahead is overly simplistic. The JWT has looked, and can look, in both directions. More specifically:

1. the JWT warns that excessive fear undermines prospects for peace. Fear is both common to human experience (a universal) and culturally constructed. There is need for the disciplining and instruction of fear even in the most precarious situations of risk;

2. the JWT resists premature militarization of a problem that might be dealt with by other means. Issues of classification are set to become both pressing and contentious as lawyers, theorists and politicians debate what kind of attack in a cyber age is equivalent to an armed attack under UN Charter Art 2(4) and 51. 'What is war'? has been a significant question since September 2001. Of interest is how JWT grappling with questions of continuity and discontinuity between ordinary and extraordinary means (policing and judicial means in relation to various kinds of injustice) help us face questions about when, for instance, cyber attacks are better dealt with under civilian, international commercial law, and when international humanitarian law (IHL) or the laws of war. I appeal to two core convictions in Grotius's writings:

'For where the power of law ceases, there war begins'. ${ }^{14}$

$>$ 'Now there are methods in law to prevent intended injuries, as well as actions for those actually committed'. ${ }^{15}$

\footnotetext{
${ }^{14}$ Hugo Grotius, On the Law of War and Peace (LWP), transl. A.C. Campbell (Batoche Books, 2001), Bk II, ch. 1, sec. II, p.61.

${ }^{15}$ Grotius, $L W P$, Bk II, ch. 1, sec. II, p.61.
} 
There are obligations upon governments to develop strong international legal frameworks to ensure that war does not begin early for want of judicial mean and 'methods in law' to prevent escalation in the use of armed force as a political option in the face of risk. While the option for war remains always on table, the classical theological

3. the JWT will treat the new challenges of the 'risk society' in a principled manner. This is not as simple as merely asserting that the familiar principles of 'right authority', 'just cause' and 'rightful intention' should be applied in all situations. It is possible that, in a cyber age, the criterion of intensity should be considered. The claim in what follows, however, is that immediacy and necessity remain the critically important principles in our moral arsenal.

\section{Risk and Fearing Well}

Present-day proponents of the JWT are invited to consider when excessive fear undermines prospects for peace, why the quest for peace and security for a given nation should not be separated from wider questions about international order, and what scope there might be for consideration of the virtues in relation to fearing wisely and well. The resources for doing this are not exclusively Christian. Ancient Graeco-Roman philosophy speaks widely and diversely to the qualities of right fear and when fear becomes a threat to reason and hinders other virtues. Schooled in these traditions, John Chrysostom teaches that fear has been implanted by God in the human soul so that danger may be avoided. ${ }^{16}$ Augustine taught that the important question is not whether one fears but what one fears. ${ }^{17}$ Aquinas wrote more fully about fear in relation to other passions and knew that there are times when aspects of the passions are uncontrollable because the bodily disposition is not subject to reason and its command. Being dependent on both the changing unpredictable external world and changes that happen in the body as a consequence of fear, like all the passions, has a rebellious side and can be insubordinate to the governance of reason.

On the other hand, condition or disposition of the body is not subject to the command of reason: and consequently in this respect, the movement of the sensitive appetite is hindered from being wholly subject to the command of reason. ${ }^{18}$

\footnotetext{
${ }^{16}$ John Chrysostom, Homily 34 on the Gospel of St Matthew 10:23. From Nicene and Post-Nicene Fathers, First Series, Vol. 10. Edited by Philip Schaff. (Buffalo, NY: Christian Literature Publishing Co., 1888.) Revised and edited for New Advent by Kevin Knight http://www.newadvent.org/fathers/200134.htm.

${ }^{17}$ Augustine, The City of God, transl. Marcus Dods (New York: Random House, 1978), Bk IX, Ch. 5, p. 285.

${ }^{18}$ Thomas Aquinas, Summa Theologica (ST) I-II, q. 17, a. 7. Translated by Fathers of the English Dominican Province, 1920. Online Edition Copyright (C) 2008 by Kevin Knight.http://www.newadvent.org/summa/index.html
} 
Citing Aristotle's Politics, Aquinas distinguishes between a properly 'political' and a 'despotic' relationship between the body and reason. ${ }^{19}$ Reasons knows about the independence and potential uncontrollability of the passions and thus tries to influence and guide the passions so that they are in accordance with the reason's commands. What matters is relation between reason ruler and the passions so that the latter participate in rationality and are subject to reason at least partially:

The condition of the body stands in a twofold relation to the act of the sensitive appetite. First, as preceding it: thus a man may be disposed in one way or another, in respect of his body, to this or that passion. Secondly, as consequent to it: thus a man becomes heated through anger. Now the condition that precedes, is not subject to the command of reason: since it is due either to nature, or to some previous movement, which cannot cease at once. But the condition that is consequent, follows the command of reason: since it results from the local movement of the heart, which has various movements according to the various acts of the sensitive appetite. ${ }^{20}$

Hence the need for the instruction and disciplining of both individuals and communities with respect to the passions in conjunction with the virtues.

Moral virtue in the JWT cannot be without the passions, including fear, but only with the passions under the governance of reason directed toward the common good of all. There is no true moral virtue without the passions (including fear) but the passions cannot be separated from questions about justice, societal order, common good, and such like. ${ }^{21}$ While there is nothing wrong with fear per se, not all fear is conducive to courage, rightful anger, peace and international order. At the least, the JWT invites consideration of when fear ceases to be virtuous, contributing to human excellence, and slips into vice.

\section{The Just War Tradition and Risk as Threat}

The JWT was familiar with questions about risk experienced as threat. Diverse voices in the tradition at least attempted to hold together questions of how to fear well in relation to questions about prevention (seeking 'to counter an adversary who either is preparing to mount an attack at a still undetermined point in the future, or, still more remotely, has acquired a military capability which, if exercised, would have devastating consequences for the defender') and defensive preemption (armed defense against an offensive that, by demonstrable signs, is imminent, while the former presupposes a longer time-frame), and to address these questions with the more familiar concerns about justice developed to deal with wrongs already

\footnotetext{
${ }^{19}$ Aquinas, ST I-II, q. 56, a. 4:

${ }^{20}$ Aquinas, ST I-II, q. 17, a. 7:

${ }^{21}$ Aquinas, ST I-II, q. 59, a. 5: 'But if by passions we understand any movement of the sensitive appetite, it is plain that moral virtues, which are about the passions as about their proper matter, cannot be without passions'.
} 
committed. ${ }^{22}$ Whether injury may be resisted even before it has been inflicted was not expressly discussed within the Decretum. As Gregory M. Reichberg notes in his study of preventive war in classical just war theory, however, a commentator explicated Gratian's observations by noting closeness to the Roman rules on self-defence and two key conditions: preemptive self-defence must be exercised in the heat of the moment; the defender should limit himself to using only so much force as was necessary to ward off the attack. The already familiar principles of immediacy and proportionality with seen to apply. ${ }^{23}$

Raymond of Peñafort later distinguished the force used in countering an attack (repulsio iniurie), i.e., defense, from any resort to force that had revenge as its primary goal. Raymond recognised the problems associated with how to define immediacy and appealed to the further principle of necessity: 'if there is no other way (si aliter non potest) to counter the threat of the ambusher. ${ }^{24}$ Like his predecessors, Vitoria placed strict limitations on what might be done in the name of defense. A person or group acting in self-defence was not allowed to seek redress for past harms or to punish wrongdoers, both would have been counted as offensive war, but was allowed limited modes of anticipatory action. Vitoria gave further considered attention to the questions of ius ad bellum. In continuity with Aquinas and mainstream scholastic traditions, he maintained that only such wrongdoing as constituted the serious violation of a right, could justify the use of force against an enemy but in an on-going just war may destroy castles to prevent further offensive. Vitoria also allows considerable scope for the exercise of discretion by a prince: 'in a just war one may do everything necessary for the defence of the public good. ${ }^{25}$ Fear in the face of threat is assumed but the principles of immediacy, proportionality and necessity win the day.

Early in what Tuck calls the modern humanist tradition, Gentili endorses preventive war and urges: 'We ought not to wait for violence to be offered us, if it is safer to meet it halfway' ${ }^{26}$ Gentili states boldly that his intent was to assert the justice of defending one's commonwealth not only against 'dangers that are already meditated and prepared' but also and especially against 'those which are not meditated, but are probable (verisimilia) and possible

\footnotetext{
${ }^{22}$ These definitions are given by Gregory M. Reichberg, 'Preventive War in Classical Just War Theory', Journal of the History of International Law 9 (2007) 5-34, at p. 6.

${ }^{23}$ Raymundus de Pennafort, Summa de poenitentia, et matrimonio, cum glossis Ioannis de Friburgo [= William of Rennes], part II, § 18, Rome, 1603. Cited in Reichberg, 'Preventive War', p.9.

${ }^{24}$ de Pennafort, Summa, ibid.

${ }^{25}$ Francisco de Vitoria, Relectio de iure belli; o, Paz dinámica, L. Pereña, V. Abril, C. Baciero, A. García, \& F. Maseda, eds., Corpus Hispanorum de Pace VI (Madrid: Consejo Superior de Investigaciones Científicas, 1981). Translation: Francisco de Vitoria, Political Writings, Anthony Pagden and Jeremy Lawrance, eds. (Cambridge University Press, 1991), 295-327, § 15. Cited in Reichberg, 'Preventive War', p.15.

${ }^{26}$ Alberico Gentili, De iure belli libri tres (Hanau: G. Antonius, 1612), I, XIV, pp. 96-107. Cited in Reichberg, 'Preventive War', p.15.
} 
(possibilia)'. He accepts the use military action against likely attack though circumscribes this action by maintaining that such action must be applied with circumspection since it is not meant to cover just any situation in which a prince has grown in power against his peers. More than sheer power arrayed against a prince is needed to justify military action: some other reason must be added for justice's sake. Under conditions of uncertainty, Gentili argues, it is justifiable to "make war through fear that we may ourselves be attacked. No one is more quickly laid low than one who has no fear, and a sense of security is the most common cause of disaster. ... We ought not to wait for violence to be offered us, if it is safer to meet it halfway. ... Therefore ... those who desire to live without danger ought to meet impending evils and anticipate them. ${ }^{27}$ Gentili does not mean only that the harm is underway but that the opponent has the capacity to inflict harm:

A just cause for fear is demanded; suspicion is not enough. Now a just fear is defined as the fear of a greater evil, a fear which might properly be felt even by a man of great courage. Yet in the case of great empires I cannot readily accept that definition, which applies to private affairs. For if a private citizen commit some offence against a fellow citizen, reparation may be secured through the authority of a magistrate. But what a prince has done to a prince, no one will make good.

But since there is more than one justifiable cause for fear, and no general rule can be laid down with regard to the matter, we will merely say this, which has always been a powerful argument and must be considered so today and hereafter: namely, that we should oppose powerful and ambitious chiefs. For they are content with no bounds, and end by attacking the fortunes of all. ${ }^{28}$

In other words, Gentili addressed directly the question of a just cause for fear and was one of the first authors in the Christian West openly to endorse the idea of preventive war on the grounds of utility.

It was Grotius who made the first concerted attempt to assess the justifiability of preventive war by reference to a systematic treatment of just war principles and was aware of tensions within the tradition with respect to fear as an instinctive response to threat and the need to treat both fear and threat within the context of law, for, as he puts it, "where judicial means fail, war begins". ${ }^{29}$ Indeed, Grotius sets his entire treatment of fear and threat from the outset within the context of law. Building on the analogy between legal action and war, Grotius observes that procedures may be directed either against offenses that have not yet been committed (non factum), or against offenses that have already been carried out: 'It has already been proved that when our lives are threatened with immediate danger, it is lawful to kill the aggressor, if the danger cannot otherwise be avoided .... We must observe that this kind of

\footnotetext{
${ }^{27}$ Gentili, De iure belli, I, XIV.

${ }^{28}$ Gentili, De iure belli, ibid.

${ }^{29}$ Grotius, LWP, Bk II, ch. 1, sec. II, p.61.
} 
defence derives its origin from the principle of self ${ }^{30}$ The intention should not be to kill but to save one's own life. The danger must be immediate and those merely planning an attack in the future may not be killed. The assumption should not be that there is a right to kill but rather 'that my knowing it will lead me to apply for the legal remedies of prevention' ${ }^{31}$ Steps will be to prevent imminent harm (damni infecti) are allowable only if the danger is immediate (praesens or quasi in puncto) ${ }^{32}$ but fear alone is an insufficient standard for decision-making about the limits of defensive action but public authorities may be justified in undertaking shortterm preemptive action only when the target of such action has been found guilty of conspiracy to commit future aggression.

Focusing initially on the conditions of private self-defense, Grotius explains that if an assailant seizes weapons in such a way that his intent to kill is manifest, the crime should be forestalled it all possible but that the assailant may be killed in situations where the risk of harm is truly immediate. Under less urgent circumstances other measures will have to be adopted. Citing Cicero who warned in On Duties Bk 1 that most injuries have their origin in fear and creates a vicious circle of fear, since he who plans to do harm to another fears that, otherwise he may himself suffer harm, Grotius is clear both that we have a right to kill the assailant (or, indeed, a robber who horrifies the property-owner by his unexpected presence) but that public authorities have particular responsibilities to undertake long-term preventive action where judicial remedies exist. ${ }^{33}$ The human condition is such that no full security can be enjoyed and protection against uncertain fears must be sought 'not from violence, but from the divine providence, and defensive precaution' ${ }^{34}$ In this, he lauds the ancient monarchs who did not shrink from exposing their acts to the judgment of mortals and gods. Fear alone is an insufficient standard for decision-making about the limits of defensive action.

Grotius's position was close to what today we might call 'last resort'. Vattel, another figure in the early modern humanist tradition, holds less strictly to the correlation of crime and punishment found in Grotius and leans toward question of what is prudential. In close similarity to Grotius, Vattel holds that 'an act in violation of justice can never be truly beneficial to the state' ${ }^{35}$ This excludes purely preventive measures except when the menacing

\footnotetext{
${ }^{30}$ Grotius, $L W P$, Bk II, ch. 1, sec. III, p.63.

${ }^{31}$ Grotius, $L W P$, Bk II, ch. 1, sec. V, p.65.

${ }^{32}$ Grotius, $L W P$, Bk II, ch. 1, sec. V, p.64. 'The danger must be immediate, which is one necessary point. Though it must be confessed, that when an assailant seizes any weapon with an apparent intention to kill me I have a right to anticipate and prevent the danger.'

${ }^{33}$ Grotius, $L W P$, Bk II, ch. 1, sec. XVI, p.69.

${ }^{34}$ Grotius, $L W P$, Bk II, ch. 1, sec. XVII, p.70.

${ }^{35}$ Emer de Vattel, Le droit des gens, 1758, in Charles G. Fenwick, The Law of Nations or the Principles of Natural Law, Applied to the Conduct and the Affairs of Nations and of Sovereigns (Washington, D.C.: Carnegie Institution, 1916), §30. Cited in Reichberg, 'Preventive War', p.52.
} 
power has the ability to oppress a neighboring country its whole existence is thereby at stake it intends to do so has shown signs (marques) of 'injustice, greed, ambition, and a will to dominate in the past. ${ }^{36}$ But Vattel allows preventive measures to be taken when the menacing power has the ability to oppress a neighboring country, intends to do so, and has shown signs (marques) of "injustice, greed, ambition, and a will to dominate" in the past, such that the whole existence of the country is thereby at stake, although it is not entirely evident the extent to which Vattel is referring here to imminent harm or a long-range plan by which the formidable power hopes one day to dominate other less powerful neighbors.

It is clear from even this brief overview that the JWT(s) do not speak with one voice. Theorists lean in different directions with respect to the tension between fear as a primitive, instinctive response to a viable threat when one's very survival might be at stake and the need amongst civilised peoples to assess preventive (ad bellum) strategies justified first and foremost on grounds of justice and of law. Present-day proponents of the classical, theological JWT face choices about where to locate themselves on the spectrum between permission and and restriction. Amidst this tension, I suggest drawing on the tradition as follows:

1. acceptance that fear is natural to the human condition, but warning against allowing fear alone to determine action because fear can either be virtuous or undermine reason;

2. recognition of frequent need for (mid- to long-term) preventive action, especially defensive and political;

3. recognition of occasional need for preemptive action but only under the strictest application of the principles of immediacy, necessity and proportionality;

4. advocacy, with Grotius, of the need for a strong international legal framework within which contextualise all relevant risk because two core convictions remain vitally important:

a. war begins where the power of law ends;

b. there are methods in law to prevent intended injuries, as well as remedies for those actually committed.

\section{Risk and the Need to Maintain 'Service Provision'}

With this in mind we, turn to our case-study. The UK National Security Strategy 2010 suggests that, in effect, cyberspace is the 'fourth utility' alongside electricity, gas and water. ${ }^{37} \mathrm{~A}$

\footnotetext{
${ }^{36}$ Vattel, Le droit des gens, $\$ 44$.

${ }^{37}$ NSS 3.28 .
} 
question facing governments is now best to maintain the service provision of cyberspace when so-called hybrid conflict is increasingly a means by which battles are fought. At the time of writing, the NATO Summit in Cardiff (September 2014) was attracting debate in the press about the conditions under which the international community distinguishes armed conflict from peacetime when different laws apply. 'Nato summit on 'high alert' for cyber attack' was Sam Jones's headline in the Financial Times. ${ }^{38}$ Nato, he reported a few weeks earlier, has been the target of several sensitively timed cyber attacks this year. Across Europe evidence has emerged in recent months of extensive and sophisticated cyber espionage campaigns being waged against diplomatic targets. ${ }^{39}$ 'Unorthodox tactics are nothing new in conflict'. Since 2010, however, 'Ukrainian computer systems have been the target of a virulent piece of computer malware known as Snake. ... Other levers of power have been overtly pulled for years'. Increasingly, however, so-called hybrid conflict comprises a kaleidoscope of regular and irregular fighting and means of undermining countries from the inside as well as intimidating through displays of strength, economic coercion, and such like: 'Russia's New Art of War'. ${ }^{40}$

Threats in cyberspace as part of hybrid warfare strategies blur the boundary between ordinary and extraordinary means in just war reasoning, and consequently render the familiar criteria of 'just cause', 'right intention', and 'right authority' increasingly difficult to apply. More specifically, it is not always clear whether and/or when a cyber attack constitutes an attack or wrongful use of force under the UN Charter or in violation of other customary international humanitarian law. Compare Article 51 (1945) with a recent statement by President Obama concerning US International Strategy for Cyber Space (2011).

\begin{tabular}{|l|l|}
\hline UN Charter Art. 51 (1945) & $\begin{array}{l}\text { US International Strategy for Cyber Space } \\
\mathbf{( 2 0 1 1 )}\end{array}$ \\
\hline $\begin{array}{l}\text { 'Nothing in the present Charter shall impair } \\
\text { the inherent right of individual or collective } \\
\text { self-defence if an armed attack occurs against }\end{array}$ & $\begin{array}{l}\text { When warranted, the United States will } \\
\text { respond to hostile acts in cyberspace as we } \\
\text { would to any other threat to our country. All }\end{array}$ \\
\hline
\end{tabular}

\footnotetext{
${ }^{38}$ Sam Jones, September 3, 2014. ft.com/uk http://www.ft.com/cms/s/0/bd29b7b6-335a-11e4-960700144feabdc0.html?siteedition=uk\#axzz3CEjQ4emC (accessed 19 October, 2014).

${ }^{39}$ Sam Jones, August 28, 2014. http://www.ft.com/cms/s/2/ea5e82fa-2e0c-11e4-b76000144feabdc0.html\#axzz3CQPNClOw (accessed 19 October, 2014).

${ }^{40}$ Sam Jones, ibid. N.b.: Three 'cyber' cases have been much discussed in recent literature: Estonia \& NATO, April 2007, where, in response to the moving of a Soviet War Memorial, hackers began interfering with Estonian government websites through distributed denial of service attacks; GeorgiaRussia, 2008, which was the known use of the internet during a conventional armed conflict to interfere with civilian use of the internet; Stuxnet, 2009-2010, when a computer worm infected computers used in the Iranian nuclear programme.
} 


\begin{tabular}{|c|c|}
\hline $\begin{array}{l}\text { a Member of the United Nations, until the } \\
\text { Security Council has taken measures } \\
\text { necessary to maintain international peace and } \\
\text { security.' }\end{array}$ & $\begin{array}{l}\text { states possess an inherent right to self- } \\
\text { defense, and we recognise that certain hostile } \\
\text { acts conducted through cyberspace could } \\
\text { compel actions under the commitments we } \\
\text { have with our military partners. }\end{array}$ \\
\hline
\end{tabular}

Article 51 is concerned with armed attacks against a Member of the United Nations but the vast majority of cyber-attacks are not carried out by government-sponsored hackers but by criminals intending to steal business secrets and financial information. ${ }^{41}$ When does a cyber operation amount to a "threat to the peace, breach of the peace, or act of aggression," such that the Security Council may authorize a response thereto? When does a cyber operation constitute an "armed attack," such that the victim-state may defend itself, even kinetically, pursuant to the right of self-defence set forth in Article 51 of the UN Charter and customary international law ${ }^{42}$

To date, the most significant scholarship on the matter is The Tallinn Manual on the International Law Applicable to Cyber Warfare that attempts to restate international law as applicable to armed conflict in the face of questions about cyber attacks. ${ }^{43}$ The Tallinn Manual is not international law but represents the views of experts asking whether a 'use of force' is only kinetic or can include cyber attacks. It looks at the characteristics of kinetic force and finds overlaps with cyber attacks in terms of the severity, immediacy, directness, invasiveness, measurability of effects, military character, State involvement, and such like. Not only kinetic attacks, it suggests, are included under existing international law as a use of force because cyber attacks too can rise to the level of an armed attack depending upon their scale and effects, that is, whether they kill persons and damage property. ${ }^{44}$ An attack on a stock exchange or shutting down the banks would not count as a use of force under international law according to this method of comparing cyber attack to kinetic force, nor would the gathering of cyber intelligence gathering outside of on-going armed conflict but over-chlorinating a water supply so that people became ill and died, or tinkering with computers in air traffic control, probably would do so.

\footnotetext{
${ }^{41}$ See Mary Ellen O’Connell, 'Cyber Security without Cyber War', Journal of Conflict \& Security Law (2012), Vol. 17 No. 2, 187-209, at p.196.

${ }^{42}$ For a useful summary of the most pertinent questions, see Michael N. Schmitt, 'Cyber Operations and the Jus ad Bellum Revisited', Villanova Law Review (2011), Vol. 56, 569-605.

${ }_{43}^{4}$ Michael N. Schmitt, Ed., The Tallinn Manual on the International Law Applicable to Cyber Warfare (CUP, 2013).

${ }^{44}$ The Tallinn Manual, p.48.
} 


\section{The Just War Tradition Today}

The JWT was never a set of criteria or check-list to be applied but ways of reasoning that asked about what kinds of military actions are justifiable, when and how not to separate immediate threats to any given party from wider national or international good, how to fear well, and much more. Of course, contexts and situations change and some aspects of hybrid warfare in the $21^{\text {st }}$ century are new. But it is unhelpful and unnecessary to view the JWT in static terms that cannot cope with rapidly changing contexts. The important question for the Christian ethicist is not whether old templates and check-lists still fit but what is demanded today in the face of known and unknown threats, and how to address the core issues of why and how justice is still a reliable metric with which to evaluate the causes and conduct of armed conflict. The following suggestions are ventured.

First, in the tradition from Aquinas et al., fearing wisely and virtuously means inter alia in ways that do not separate seemingly immediate risks to one nation-state from wider questions about international order and common good. This might include governmental awakening of some to the need for a security strategy comparable to discussions in previous decades of military preparedness. This is different from weak governments manipulating public anxiety to increase electoral advantage or other powers: 'Better in that situation to summon the courage to oppose power with power and have the wisdom to remind ourselves that because we share the same human nature with our enemies, we are equally susceptible to their vices' ${ }^{45}$

Second, we may affirm with Grotius that a strong international legal framework is needed if threats are to be faced in ways do not fall foul of this irrationality, and if methods in law are to be used to prevent intended injuries as well as react to those already committed. It is regrettable that The Tallinn Manual when first published did not include attention to peacetime international law governing telecommunications, the security of international financial relations, and such like. Consider the analogy, to chemical weapons, urges Mary Ellen O'Connell. Chemicals may be turned into powerful weapons of mass destruction, which defence officials need to plan for, but the non-military sector is where most chemical use and regulation is found; the international community could not tolerate the immensely useful chemical sector being dominated by the military. ${ }^{46} \mathrm{O}$ 'Connell is concerned about the rush to designate the majority of cyber attacks as acts of war: '[T]he military paradigm is the wrong

\footnotetext{
${ }^{45}$ Robin Lovin, 'Security and the State: a Christian Realist Perspective on the World since 9/11' in Esther D. Reed and Michael Dumper, Eds, Civil Liberties, National Security and Prospects for Consensus: Legal, Philosophical and Religious Perspectives (CUP, 2014).

${ }^{46}$ Mary Ellen O'Connell, 'Cyber Security and International Law', Chatham House 29 May, 2013. http:/www.chathamhouse.org/sites/files/chathamhouse/public/Research/International\%20Law/290512s ummary.pdf (accessed 19 October, 2014).
} 
one for cyber security'. ${ }^{47}$ The military paradigm won't be the wrong one for all aspects of cyber security but O'Connell's warning is well made: 'where the power of law ceases, there war begins'. A strong international community capable of strengthening, as appropriate, law governing trade, economic rights, non-intervention, and more, is necessary alongside attention to the law of self-defence.

Third, like predecessors who stood variously in the JWT(s), we face questions today about whether to err toward restriction or permissiveness in interpretation of criteria and handling of questions about justice. Michael N Schmitt of the US Naval War College might well be correct that the current The Tallinn Manual standards will not survive for long. To date, he says, states have refrained from characterizing any cyber operations conducted outside the context of an on-going armed conflict as either international or non-international armed conflict. ${ }^{48}$ 'Be that as it may, cyber operations will in the future inevitably present difficult conflict classification challenges for States. With regard to international armed conflict, attribution of cyber operations conducted by non-State actors will likely prove even more problematic than the attribution to States of kinetic actions has been in the past. In the context of non-international armed conflict, qualification as an organized armed group will prove increasingly complex as the structures, means and prevalence of virtual organization grow and evolve. Perhaps most importantly, the approach taken to the interpretation of the term 'armed' is, although presently reflecting lex lata, unlikely to survive. ${ }^{49}$ As States and non-State actors engaging in ever more destructive and disruptive cyber operations and societies becoming deeply dependent on the cyber infrastructure, Schmitt expects that state practice accompanied by opinio juris will result in a lowering of the current threshold.

The law of cyber-armed conflict is necessarily a work in progress and will remain so for the immediate future. The question is how international law will change to take account of evolving threats, and how the most powerful nation-states in the international arena will exercise leadership. With some states and non-state actors engaging in ever more destructive and disruptive cyber operations, and with societies becoming deeply dependent on the cyber infrastructure, it is inevitable and desirable that international law will develop but the JWT calls for rigorous and renewed engagement with the principles of immediacy, necessity and proportionality. Unilateral lowering of current thresholds for military action could bring disastrous results.

\footnotetext{
${ }^{47}$ O’Connell, ibid.

${ }^{48}$ Michael Schmitt, 'Classification of Cyber Conflict', Law Journal of Conflict and Security Law Vol. 17, Issue 2, 245-260, at p.259.

${ }^{49}$ Schmitt, 'Classification of Cyber Conflict', p.260.
} 
Dr Esther D. Reed, Associate Professor Theological Ethics, Theology and Religion, University of Exeter, EX4 4RJ.

E.d.reed@exeter.ac.uk 